\title{
How to Improve Speaking Skill using Treffinger Learning Model?
}

\author{
Rizqi Akbarani \\ Sebelas Maret University \\ Email: kikiakbar.ka@gmail.com
}

E-ISSN : 2579-4574

P-ISSN : 2549-7359

\begin{abstract}
This research analyzed the implementation of Treffinger learning model in teaching speaking skill. This research used $\mathrm{n}$ classroom action research by applying treffinger learning model in speaking class. In collecting the data, research used observation to observe the implementation of Treffinger learning model during teaching learning process and used speaking test to find the improvement of students' speaking skill during implementation of Treffinger learning model. The research finding showed that the implementation of Treffinger learning model can improve the students' speaking skill. Thereore, it can be concluded that Treffinger learning model is acceptable to be used as teaching learning model in teaching speaking.
\end{abstract}

Keywords: Treffinger learning model, teaching speaking, speaking skill, English Foreign Learning

\section{https://ojs.unm.ac.id/eralingua}

\section{INTRODUCTION}

English is international language which has been spoken as communication tool for many sectors such as education, technology, diplomacy, economic, and industry. As an international language, English is needed by people in globalization era where English is learnt by almost all of schools all over the world, from formal schools up to non-formal ones. There are four language skills that have to be learnt by students in learning English. There are speaking, reading, writing, and listening. Speaking is one of the four language skills that used by people in communication with others to achieve certain goals or to express their opinions, intentions, hopes, and viewpoints.

Rahmat (2019) said that the mastery of speaking skills in English is a priority for many second or foreign language learners. Students consequently often evaluate their success in language learning as well as the effectiveness of English course on the basis of how well they feel that they have improved their speaking skill. In the process of improving speaking skill, the ideal conditions of speaking skill could be seen from the indicators of speaking where the indicators of speaking are pronunciation, vocabulary, grammar, fluency, and comprehension. Students' 
pronunciation, students can produce and pronounce word easily and understand the words that are produced by the other speaker (Abrar et all., 2018; Cerezo et all., 2019). Another aspect is vocabulary which is the important part in speaking where students can rise appropriate diction which is used in communication (Wood et all., 2018; August et all., 2018).

The third aspect is grammar, the students can manipulate structure and distinguish appropriate grammatical form in appropriate one (Miller et all., 2018; Ngo, 2018). Another aspect is students' fluency, students can produce continuous speech without causing comprehension difficulties or a breakdown of communication. It can be said that students can make dialogue and give response well without getting difficulty (Sharma, 2018; Wamnebo et all., 2018). The last aspect is comprehension which is the students' ability in speaking where they can answer or express well and correctly in oral communication (Barrière et all., 2019; Uchikoshi et all., 2018).

In addition, there are some ideal characteristic of speaking activity in achieving successful speaking skill. First, when the students talk a lot and the time is not only taken up with teacher talk. The second is students' participation. It means that classroom discussion is not dominated by minority talkative participants; all get a chance to speak and give fair evenly distributed contributions. Third, students have high motivation where students are eager to speak because they are interested in the topic and have something new to say about it, or they want to contribute to achieve a task objective. Lastly, the language use is of an acceptable level. Students express themselves in utterances that are relevant, easily comprehensible to each other, and acceptable level of language accuracy to be able to build good interaction among students. Based on the ideal condition of speaking skill above, it can be said that encouraging speaking skill in language learning, especially in English is not easy thing.

According to Brown (2001: p. 270), there are some features that make speaking as a difficult language skill. They cover clustering, redundancy, reduced forms, performance variable, colloquial language, rate delivery, stress, rhythm, intonation of English and interaction. Moreover, the problems in speaking are; (1) less vocabulary, it makes students reluctant in selecting or producing appropriate word; (2) less grammatical understanding, it affects their correctness in sentence production; (3) students' pronunciations, it influences their accuracy and listeners' understanding in oral communication; and (4) comprehensible, the students' ability to solve the difficulties such as, language experience, the utterances production in correct vocabulary, grammatical structure, pronunciation, and the delivery of oral communication; (5) Organization, it affects how the students present and arrange 
their speaking to make the listener easier to understand and remember the information.

There are learning models that can be used to teach speaking, for example Treffinger learning model. Treffinger learning model is one of cooperative learning model that has concept of creative problem solving where Treffinger learning model is the revision from creative problem solving. Treffinger learning model was created by Donald J Treffinger, the president of Center of Creative Learning Inc Sarasota, Florida where he modified six steps in creative problem solving becomes three major components (Huda, 2013). Treffinger learning model is considered as one of the learning model that can create the situation for students where they can interact with other actively in the language and make the learning language more meaningful. Students learn based on problem, manage the problem, and try to solve the problem together. It is hoped to be able to improve and enhance the students' speaking skill in daily life communicatively and actively (Treffinger et all., 2003).

Moreover, Treffinger learning model is fun and motivating where quieter students get the chance to express themselves in a more open. Based on the major component of Treffinger learning model and steps from the expert, researcher adapted some ideas on how to use Treffinger learning model in learning speaking.

a. Setting goal. This stage is setting goal where teacher informs competency to be achieved in learning. In this research, teacher wants to improve students' speaking skill in asking and giving opinion.

b. Exploring data. In this step, teacher demonstrates or presents a natural phenomenon that can attract the curiosity of students. Teacher shows picture or video to the students about social problems. Teacher also gives explanation and example about asking and giving opinion in English based on the picture or video. In this research, the problems were flood, using mobile phone for children, juvenile delinquency, and the effect of social media. This step can improve students' grammar, vocabulary, and pronunciation.

c. Formulating problems. In this step, teacher gives students the opportunity to identify problems. Teacher creates students group and invites them to discuss the problems with their group.

d. Generating ideas. Teacher gives opportunity to identify the problem, raise their ideas, and decide the alternative solutions. Besides, teacher also gives students time to express their ideas.

e. Developing solution. After generating their ideas, teacher asks students to develop the solutions. Teacher encourages students to collect appropriate information and carry out experiments to get an explanation and problem solving. In this step, the students were given opportunity of conveying the alternative solution. They write their opinions and solutions on the paper. This 
step can improve the students' creativity and increase the students' interaction skill.

f. Building acceptance, in which after they discuss and write their discussion result, every group presents their discussion in front of the class and other groups give comment, feedback, question, and suggestion. Teacher checks the solution obtained by the students group. In the last, teacher helps students to make summary about the discussion result and the problem solutions. Teacher can improve the students' fluency, vocabulary, and comprehension in this step (Treffinger et all., 2003).

\section{RESEARCH METHOD}

This research used classroom action research. In this research, researcher used observation and test (pretest and posttest) to collect the data. The data consisted of qualitative and quantitative data. Observation is used to collect the qualitative data. Researcher did observation as ways of finding out more about the students' responses, students' behaviors, and students' activities during the teaching and learning process. The quantitative data are obtained from test. The researcher used test in the end of every cycle. The tests were pre test, post test in cycle 1, post test in cycle 2. Pre test was held before the action. The purpose of this test was to check the students' skill in speaking. The procedures of the pre-cycle speaking test are researcher asked students to introduce themselves and tell about their family in front of the class. After that, researcher gave scores using the scoring rubric of speaking. This research had two post test where one post test for each cycle. The purpose of post-test is to check the students' progress in speaking after they were taught by using Treffinger learning model. The results were used to find the improvement of the students' speaking skill.

Furthermore, the researcher described the data to give any information about using Treffinger learning model in teaching speaking using qualitative technique analysis and quantitative technique analysis. Qualitative technique analysis was the researcher analyzed the data of using Treffinger learning model in speaking through observation, interview, field note, photograph, and audio recording. There are five steps in analyzing data: (1) The first step is assembling the data. In this step, the researcher has to collect data from instruments like interview, observation, and field note. In this step, broad patterns should begin to show up which can be compared and contrasted to see what fits together. (2) Coding the data. It is a process of attempting to reduce the large amount of data that may be collected to more manageable categories of concepts, themes, or types.

Data analysis become messier and coding becomes less clear cut when the researcher dealing with diary entries, classroom recording, or open-ended survey questions. (3) Comparing the data where the researcher code the data and compare 
it in order to know whether there is repetition, developing, and differences after the action or not. (4) Building interpretation. It is the point where you move beyond describing, categorizing, coding, and comparing to make some sense of the meaning of the data. It needs creative thinking that concern with the underlying concepts and developing theories about why some problems emerged. (5) Reporting the outcomes where in this step, it involves presenting an account of the research for others. Quantitative technique analysis was used to analyze the speaking test before and after each of the cycle (pre-test and post-test). From the test, the researcher found the comparison of students' speaking skill before and after the research. The researcher also compared the mean using paired sample ttest. It aims to know wheather there is a significant increase between mean score of pre-test and post-test.

\section{RESULTS AND DISCUSSIONS}

The data was taken from observation and test. After implementing Treffinger learning model in teaching speaking, the results showed improvement of score in all of speaking aspects: pronunciation, vocabulary, grammar, fluency, and comprehension that could be seen from the results of pretest and posttest which finally reached minimum score of the passing grade. The overall test results from pretest and posttest can be seen in table 1:

Table 1 Progress Score Summary from Pretest to Posttest

\begin{tabular}{lccccc}
\hline & Pronunciation & Vocabulary & Grammar & Fluency & Comprehension \\
\hline $\begin{array}{l}\text { Mean } \\
\text { score of } \\
\text { pretest }\end{array}$ & 56.15 & 59.62 & 66.54 & 58.46 & 54.62 \\
\hline $\begin{array}{l}\text { Mean } \\
\text { score if } \\
\text { posttest 1 }\end{array}$ & 70 & 77.69 & 82.31 & 65 & 63.46 \\
& & & & & \\
$\begin{array}{l}\text { Mean } \\
\text { score of } \\
\text { posttest 2 }\end{array}$ & 81.54 & 83.85 & 92.31 & 83.08 & 71.92 \\
& & & & & \\
\end{tabular}

Based on the table above, researcher found that Treffinger learning model can improve students' speaking skill. It was relevant with Alhadad (2015), who stated that Treffinger model enabled the students to express their ideas through speaking and/or writing. From the research, Researcher found that Treffinger learning model improved all aspects of speaking; they are pronunciation, grammar, vocabulary, 
fluency, and comprehension. The pronunciation aspect increased, it was shown by the improvement of main score of pronunciation from 56.15 to 81.54 .

The vocabulary aspect also improved from 59.62 to 83.85 . They spoke better by using new vocabularies in the posttest because Treffinger was also beneficial to enhance grammar in speaking. It could be seen that the mean score of grammar increased from 66.54 to 92.31. Fluency aspect also improved, it was shown that the mean score of fluency increased from 58.46 to 83.08 and the mean score of comprehension aspect improved from 54.62 to 71.92 . It was relevant with Alhadad (2015) in his research that Treffinger learning model can be applied as an alternative model of learning in order to improve the students' communication skills. It is known that speaking is a part of communication skills. (2015: p. 38)

In teaching learning process, the implementation of Treffinger learning model was applied well. The students looked interested in following activity. Treffinger learning model also improved the students' behavior during teaching learning activity where they were more active to deliver their idea and they did assignments more seriously and enthusiastically. It was similar to Huda's argument (2013) that Treffinger learning model make the students more active in learning and have confidence to speak their ideas.

\section{CONCLUSIONS}

Based on the data analysis, research findings, and discussions in implementing Treffinger learning model to improve the students' speaking skill, it can be concluded that this research is successful because the students' speaking skill improves by implementing Treffinger learning model. It is proven by the improvement of the students mean score of speaking test. The improvement contains all aspects of speaking which are pronunciation, grammar, vocabulary, fluency, and comprehension. Meanwhile, Treffinger learning model also can increase the students' behavior in teaching learning process. The students were more active to deliver their idea and they did assignments more seriously and enthusiastically. The students were more enthusiastic and interested in teaching learning process. They did the tasks seriously when they discussed and presented their tasks. Most of students were not bored when following the lesson. They were active in discussing by sharing ideas and become more responsible in doing the task. They also enjoyed in discussing the material, solved the problem, and could share their ideas creatively.

\section{REFERENCES}

Abrar, M., Mukminin, A., Habibi, A., Asyrafi, F., Makmur, M., \& Marzulina, L. (2018). "If our English isn'ta language, what is it?" Indonesian EFL Student 
Teachers' Challenges Speaking English. The Qualitative Report, 23(1), 129145.

Alhaddad, Idrus., Kusumah, Yaya S.; Sabandar, J., \& Dahlan, Jarnawi a. (2015), Enhancing Students' Communication Skills through Treffinger Teaching Model. IndoMS-JME journal 6 (1), 31-39

August, D., Artzi, L., Barr, C., \& Francis, D. (2018). The moderating influence of instructional intensity and word type on the acquisition of academic vocabulary in young English language learners. Reading and Writing, 31(4), 965-989.

Barrière, I., Kresh, S., Aharodnik, K., Legendre, G., \& Nazzi, T. (2019, April). The comprehension of 3 rd person singular by nyc english-speaking preschoolers. In Three streams of generative language acquisition research. Selected papers from the 7th meeting of Generative Approaches to Language Acquisition-North America, University of Illinois at UrbanaChampaign (Vol. 63, pp. 7-33).

Brown, H. Douglas, (2001). Teaching by Pronciples: An Interactive Approach to Language. New York: Longman

Cerezo, R., Calderón, V., \& Romero, C. (2019). A holographic mobile-based application for practicing pronunciation of basic English vocabulary for Spanish speaking children. International Journal of Human-Computer Studies, 124, 13-25.

Huda, Miftahul. (2013). Model Model Pengajaran dan Pembelajaran: Isu-Isu Metodis dan Paradigmatis. Yogyakarta: Pustaka Pelajar.

Miller, R. D., Correa, V. I., \& Katsiyannis, A. (2018). Effects of a story grammar intervention with repeated retells for english learners with language impairments. Communication Disorders Quarterly, 40(1), 15-27.

Ngo, T. T. H. (2018). A Review on Grammar Teaching of English Textbook Entitled "Skillful: Listening and Speaking, Student's Book Pack 2" by David Bohlke and Robyn Lockwood. Social Science and Humanities Journal, 764-775.

Rahmat, A. (2019). Enriching the Students Vocabulary Mastery in Speaking through Engage, Study, Activate Method. Metathesis: Journal of English Language, Literature, and Teaching, 3(1), 92-110.

Sharma, D. R. (2018). Action Research on Improving Students' Speaking Proficiency in Using Cooperative Storytelling Strategy. Journal of NELTA Surkhet, 5, 97105.

Treffinger, Donald J., Isaksen, Scott G., \& Dorval, K Brian. (2003). Creative Problem Solving (CPS Version 6.1 TM): A Contemporary Framework for Managing Chance. Center for Creative Learning, Inc. and Creative Problem Solving Group, Inc. Website: www.cpsb.com 
Uchikoshi, Y., Yang, L., \& Liu, S. (2018). Role of narrative skills on reading comprehension: Spanish-English and Cantonese-English dual language learners. Reading and writing, 31(2), 381-404.

Wamnebo, W., Hanapi, H., Bugis, R., \& Handayani, N. (2018). Students' Speaking Skill in Oral Descriptive Text by Using Video at Tenth Grade in SMA Negeri 1 Namlea. Jurnal Jupiter, 16(2), 98.

Wood, C., Fitton, L., Petscher, Y., Rodriguez, E., Sunderman, G., \& Lim, T. (2018). The effect of e-book vocabulary instruction on Spanish-English speaking children. Journal of Speech, Language, and Hearing Research, 61(8), 19451969. 